\title{
Betri hagur - bætt heilbrigði
}

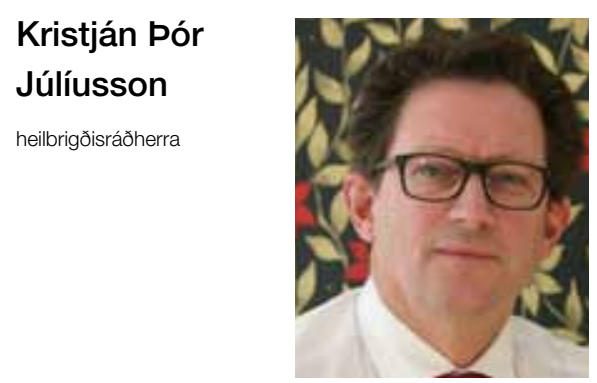

kristjanj@althingi.is

Með yfirlýsingu peirri sem fulltrúar ríkisstjórnarinnar, Læknafélags Íslands og Skurðlæknafélags Íslands undirrituðu fyrir skömmu var rammaður inn eindreginn vilji stjórnvalda til að efla heilbrigðiskerfið. Par er lögð áhersla á mikilvægi heilbrigðiskerfisins og vilja hlutaðeigandi til að styrkja pað og bæta. Hér er pví um tímamót að ræða. Мeð erfiða kjaradeilu að baki kjósa nú peir sem áður tókust hart á, að deila sameiginlegri framtíðarsýn. Pessi sýn lýtur ekki eingöngu að stöðu peirra sem komu að kjarasamningum eða yfirlýsingunni. Hún varðar einnig almenning í landinu sem trúir og treystir á að peir sem stýra heilbrigðismálum pjóðarinnar geri pað í eins mikilli sátt og samvinnu og unnt er. Рað er skylda okkar allra sem fara með pennan mikilvæga málaflokk.

Í störfum mínum sem heilbrigðisráðherra hef ég sannfærst um að ein stærsta áskorunin sem við Íslendingar stöndum frammi fyrir á komandi árum sé ao tryggja og auka samkeppnishæfni íslenska heilbrigðiskerfisins. Við purfum að horfast í augu við pá staðreynd að íslenskir heilbrigðisstarfsmenn eru eftirsóttir í öðrum löndum. Par skipta launakjör auðvitað miklu en ekki síður sá aðbúnaður og sú aðstaða sem boðið er upp á. Við stöndum pví ekki aðeins frammi fyrir miklum fjárfestingum í innviðum heldur ekki síður í peim mikla mannauði sem er innan heilbrigðiskerfisins, meðal annars í peim tilgangi hafa framlög í vísinda- og rannsóknarsjóði verið stóraukin.

Meðal helstu áhersluatriða ríkisstjórnarinnar er bygging nýs Landspítala og markviss endurnýjun tækjabúnaðar í heilbrigðiskerfinu í samræmi við tækjakaupaáætlun sem kynnt var haustið 2013, en hvoru tveggja er ætlað að bæta starfsaðstöðu heilbrigðisstarfsfólks og pjónustu við almenning. Auknu fjármagni hefur verið veitt til heilbrigðismála og breytingar gerðar í peim tilgangi að auka skilvirkni. Um leið er stefnt að aukinni samvinnu heilbrigðisstofnana og markvissari verkaskiptingu, auk pess sem íslenska heilbrigðiskerfið á að verða samkeppnishæft við pað sem tíðkast annars staðar á Norðurlöndum.

Aukin fjárframlög á fjárlögum endurspegla pær áherslur í heilbrigðismálum sem ég hef boðað og falla undir verkefni áætlunarinnar Betri heilbrigðispjónusta. Efling heilsugæslunnar er eitt okkar helsta forgangsmál og við sjáum nú raunaukningu á framlagi til heilsugæslu og sjúkraflutninga. Pessari aukningu verður varið til verkefna eins og fjölgunar á sérnámsstöðum í heimilislækningum og heilsugæsluhjúkrun, verkefni um miðlæga símaráðgjöf um heilbrigðispjónustu á landsvísu og innleiðingu pjónustustýringar í heilbrigðiskerfinu, svo fátt eitt sé nefnt.

Sameining heilbrigðisstofnana var eitt verkefna áætlunarinnar um Betri heilbrigðispjónustu. Par hef ég lagt áherslu á að ljúka pví verkefni sem hófst fyrir löngu, að sameina stjórnun stofnana pannig að sama skipulag gildi um stjórnun heilbrigðispjónustu í öllum heilbrigðisumdæmum landsins. Sú vinna gengur vel.

Heilbrigðispjónusta á Íslandi hefur lengi staðið framarlega í samanburði við önnur lönd og árangur á mörgum sviðum verið með pví besta sem pekkist. Ungbarnadauði hefur árum saman verið lægstur hér í samanburði við aðrar Evrópupjóðir og fáar pjóðir eru langlífari en Íslendingar. Hvort tveggja segir mikið um heilsu og velferð pjóða.

Almennur og greiður aðgangur að heilbrigðispjónustu er eitt af meginmarkmiðum íslenska heilbrigðiskerfisins. Allir landsmenn eiga sama rétt til heilbrigðispjónustu. Heilbrigðiskerfið er að langstærstum hluta fjármagnað af hinu opin- bera en sjúklingar greiða pó ákveðinn hluta með notendagjöldum.

Heilsufar landsmanna hefur áhrif á flesta pætti samfélags okkar. Heilbrigði er mikilvægt fyrir menntun, samfélagsog atvinnupátttöku, efnahagslega próun og samfélagið í heild. Heilbrigðismál eru mál ólíkra geira samfélagsins og varða allt stjórnkerfið og par með öll ráðuneyti og sveitarfélög. Pví er mikilvægt að í allri stefnumótun, bæði opinberra aðila og annarra, sé hugað að lýðheilsu. Ábyrgð einstaklinga á eigin heilbrigði parf að fara saman við ábyrgð stjórnvalda og stofnana samfélagsins sem með stefnu sinni, ákvörðunum og aðgerðum geta haft mikil áhrif á vilja, getu og aðstæður fólks til að lifa heilsusamlegu lífi á öllum aldursskeiðum. Gott heilsufar er ekki aðeins mikilvægt fyrir vellíðan fólks, heldur er pað jafnframt pýðingarmikið fyrir sérhvert pjóðfélag og efnahag pess.

Miklar áskoranir bíða okkar. Öldrun pjóðarinnar er staðreynd sem ætti ekki að koma neinum á óvart. Breytingin er óumflýjanleg og okkur ber að búa í haginn pannig að samfélagið geti tekist á við breytta aldurssamsetningu og pað sem henni fylgir. Sú vinna á að miða að pví að styrkja stöðu Íslands í alpjóðlegum samanburði, hvort sem litið er til lýðheilsu pjóðarinnar eða helstu mælikvarða sem fela í sér mat á gæðum, öryggi, skilvirkni og hagkvæmni heilbrigðiskerfisins, svo sem varðandi aðgengi, meðferðarárangur, lyfjanotkun, réttindi sjúklinga og allt pað er lýtur að heilbrigði landsmanna.

Hér sem annars staðar mun hnattvæðing, lýðpróun og efnahaglegur óstöðugleiki auka álag á heilbrigðispjónustuna. Af pví leiðir að öll svið samfélagsins verða að takast sameiginlega á við pau viðfangsefni sem við blasa, okkur öllum til hagsbótar og velsældar.

Better economy - improved health Kristjan Thor Juliusson, Minister of Health in Iceland 